\title{
Dawet Ireng Development Model as Purworejo's Distinguished Local Product
}

\author{
Agus Fitri Yanto \\ Politeknik Sawunggalih Aji - Kutoarjo \\ agusfitri2011@gmail.com \\ Danis Imam Bachtiar \\ Politeknik Sawunggalih Aji - Kutoarjo \\ danisbachtiar77@gmail.com
}

\begin{abstract}
Ministry of Cooperatives and Small and Medium Enterprises data shows that in 2012, MSMEs absorb $97.16 \%$ of all workforce in Indonesia. Even UMKM's contribution to the value of Indonesia's Gross Domestic Product reached 59.08\%. While MSMEs in Central Java Province, the biggest supporting sector is trade which in 2011 reached 28,362 units. With $40.38 \%$ of total SMEs in Central Java, MSMEs trade proved to provide great support for the dynamics of Central Java and nationally economy, including SMEs in Purworejo District. Purworejo has a variety of local products that have penetrated national and international markets such as VCO, mangosteen peel herbal products and coconut sugar powder. However, various potentials and superior products Purworejo it must be increasingly competing with various modern products. The success of some products Purworejo SMEs apparently can not be followed by other products that actually become icon Purworejo, such as clorot, lompong cake, and dawet ireng. When dawet ireng increasingly widely known in various regions, it is in Purworejo felt to be an ordinary product and far from a distinctive impression. The position of dawet ireng increasingly much different from more modern beverage products and the present. This is apparent from the more demanding of a similar kind of drinks. If this is left then dawet ireng increasingly shifted. Based on this matter, it is necessary to design dawet ireng development model as a unique local product of Purworejo so it is more competitive and really become the regional icon that can be equated with modern beverage products today.
\end{abstract}

Keywords: development model, local product, dawet ireng

JEL Classification: M11, M31, M38

\section{INTRODUCTION}

The existence of Micro, Small and Medium Enterprises (MSMEs) amid the dynamics of the national economy increasingly has a strategic position. Although business competition with the manufacturing industry and modern business is increasingly complex, MSMEs have a 
significant contribution to national economy growth. Data at Ministry of Cooperatives and Small and Medium Enterprises shows that in 2012, MSMEs absorbed $97.16 \%$ of all workers in Indonesia. The MSMEs contribution to the Indonesia's Gross Domestic Product (GDP) reached $59.08 \%$ and through taxes reaching Rp 4,869,568,100,000,000 (Pramono, 2015).

While in Central Java Province. The number of MSMEs also tends to increase. Data from the Central Java Cooperative and MSME Office shows that from 2009 to 2011 the number of MSMEs increased every year. The supporting sector with the largest number is from trade MSMEs which in 2011 reached 28,362 units (Darwanto, 2013). With a total of $40.38 \%$ of the total MSMEs in Central Java, trade MSMEs are proven to provide not small support for the dynamics of Central Java and national economy.

Tabel 1. Number of MSMEs in Central Java, 2009 - 2011

\begin{tabular}{lrrr}
\hline \multicolumn{1}{c}{ Type of MSMEs } & \multicolumn{1}{c}{2009} & \multicolumn{1}{c}{2011} \\
\hline Non-agricultural production & 20.682 & 21.205 & 23.374 \\
Agricultural & 9.385 & 9.775 & 10.097 \\
Trading & 28.172 & 28.247 & 28.362 \\
Sercices & 7.639 & 8.389 & 8.389 \\
Total & 65.878 & 67.616 & 70.222 \\
\hline
\end{tabular}

Source: Central Java Cooperative and MSME Office, 2012 (Darwanto, 2013)

The great support of MSMEs for the local, regional and national economy certainly must always be optimized, one of which is by increasing the competitiveness of MSME products towards modern products, manufacturing and the present. The dynamics of business driven by MSMEs must be able to contribute for maximum area.

Based on the results of the 2010 Competitiveness Survey (SDS 2010) in Central Java as a combination result of ProInvestment Survey and Business Climate Survey. It was found that the highest criteria for the business dynamics sub-index were Wonosobo Regency with a score of 7.52. Other regions that occupy the position below are Banyumas, Salatiga City,
Boyolali and Jepara. Compared to the results of 2007, Wonosobo and Banyumas showed a significant increase. (www.bi.go.id, 2010).

From SDS 2010 data indirectly shows that in Central Java there are still many districts and cities with business dynamics not yet optimal. This condition is inseparable from various problems that must be faced by MSMEs. Based on a survey conducted by Hamid and Susilo (Pramono, 2015) in the Yogyakarta region, there were several problems faced by MSMEs: (1) Marketing; (2) Capital and funding; (3) Innovation and utilization of information technology; (4) Use of raw materials; (5) Production equipment; (6) Absorption and empowerment of workers; (7) Business development 
plan; (8) Readiness to face the external environment challenges. Regarding various problems faced by MSMEs, a strategy is needed to overcome them. With different demographic characteristics and regions, it is certain that MSMEs in Central Java have similar problems.

These problems were also faced by MSMEs in Purworejo. Even though they have to face various problems, Purworejo has variety of local products that have penetrated national and international markets such as Virgin Coconut Oil, processed products of mangosteen peel and ant sugar. For example in August 2017, Purworejo's ant sugar successfully penetrated in Sydney Australia and Colombo Sri Lanka. Purworejo's ant sugar currently reaches up to 220 tons per month which is exported to various countries (krjogja.com, August 11, 2017).

In the midst of success in national and international markets penetration, Purworejo's various products have to be increasingly competitive with modern and contemporary products. The success of several Purworejo MSME products has not yet been able to be followed by other products which have become the icons of Purworejo. Until now, the typical icon of Purworejo products has not been able to develop properly. In addition to clorot, lompong cakes, and dawet ireng as a natural local drinks. Dawet ireng has become a trend and is widely known in various regions since a few years ago. Its carrying capacity for the regional economy also cannot be considered trivial. Dawet ireng contribution to family income in Butuh district as the main center of dawet ireng is included in the high category because it reaches 70.68\% (Setiawati et al, 2013).

The increase of modern and contemporary products has shifted the dawet ireng existence as a typical drink. Dawet ireng is widely known in various regions, but in Purworejo it is becoming a regular product and far from typical. The emergence in various regions has intensified competition between dawet ireng sellers. This condition ultimately affects the dawet ireng quality and image as a typical Purworejo product that's not noticed.

Dawet ireng is increasingly different from similar products that are more modern. This can be seen from the more desirable types of drinks compared to dawet ireng. If this is allowed then dawet ireng is increasingly abandoned. It is necessary to design dawet ireng development model as Purworejo's distinguished local product to be more competitive and become an icon that can be compared with modern drinks today.

\section{LITERATURE REVIEW}

\section{Brand Image and Products Quality}

A good marketing plan is very positive for the business operations. In a specific marketing plan, the development of a strong product image and promotion is highly recommended. To develop markets 
competitively, cost strategies can be applied to products with quality and attribute types (Hossain, 2007).

Lin $(2007: 121)$ in his research found a significant difference in the correlation between brand image and consumer purchase intentions. Consumer buying intentions are influenced by brand image where the higher the status of brand image, the more buying intention that exists. There are several things that must be considered business actors in marketing their products that is (Lin, 2007:130):

1. Brand image indeed increases consumer purchase intention due to the formation of positive image. Business actors can take advantage of added value, such as expanding product line or save promotion cost in new market.

2. Consumers with different levels of product knowledge will use different methods to evaluate a product so that complete product information is indispensable in marketing.

3. The discounted price leads to interference the correlation between brand image and purchase intention. So companies should discount prices carefully, such as reasonable arrangements regarding the price.

In research on students using an explanatory research approach, it is known that product quality, promotion, and brand image have a positive influence on purchasing decisions (Saputra et al., 2014). The better innovation of product quality, increasing the advertisements and sales promotions frequency, must be done appropriately to support the product purchases optimization.

The same thing was found by Ambolau et al. (2015) to determine brand awareness and brand image effect on purchasing decisions and the influence of brand awareness and brand image simultaneously on purchasing decisions. His research show that brand awareness has a significant effect on purchasing decisions. Brand image also has a significant effect on purchasing decisions. Brand awareness has the most dominant influence on purchasing decisions. It is must always be maintained and improved to support strengthening brand image and increase product purchases by consumers.

As a tool that can positively change purchasing behavior, brand image plays an important role in improving business performance (Sapna \& Sheetal, 2016). Brands as valuable assets, also serve several valuable functions. For customers, brands can simplify choices, promise a certain level of quality, reduce risk, and increase trust. It is known that the brand image has a strong positive effect on consumer purchasing behavior. Consumers are increasingly aware that branded products represent or symbolize their personality.

\section{Promotion and Consumer Decisions} Consumer studies in Puerto Rico show that both monetary and nonmonetary promotions can increase brand loyalty and this is in contrast to previous research findings. If a few years ago 
promotions were deemed less effective when done traditionally through ad campaigns or sales promotions, this has now changed with sales promotions leading to local and national marketing solutions (Mendez, 2015). Even sales promotion has become one of the most preferred marketing communication methods.

Synergistic with Mendez's research, in Chakrabortty et.al. (2013) it is known that sales promotion is most effective on the traveling consumer. In addition promotions and advertising sales are much more effective where simple promotional signals can lead consumers to buy products. However, advertising activities should be integrated with other promotional activities to increase product sales growth.

In the Oladepo (2015) study of the influence of brand image and promotional mix on beverage purchasing decisions at Lagos State Nigeria it was found that brand image and promotion mix in the form of advertising, sales promotion and personal sales had a major influence on consumer purchasing decisions.

Promotion combination of product with good brand integrity will make consumers buy it and make repeat purchases, and also increase other opportunities or prospects. Combination of promotional mixes will be increase market share and profits.

But it must be remembered also that the decision making process by consumers consists of the stages of problem recognition, information seeking, and evaluation of alternatives, purchases, and postpurchase evaluations. However, the buying decision process is possible not through all of these stages (Pride \& Ferrell in Sagala, 2012). In this case the repurchase of a product is actually influenced by promotion and price. Advertising combined with sales promotions and other marketing mixes can have a sustainable effect.

Widyastuti and Santosa (2016:104) in their research to understand the influence of attitude, perceived value, concludes that consumers are ready to pay for extra value, will pay a premium price, and will repurchase only if they perceive extra value from the product.

\section{Marketing Mix and Consumer Satisfaction \\ Durrani et al. (2015) in his} research on the impact of brand image on purchasing choices and the level of satisfaction of adolescent consumers in Karachi showed that advertising had a significant effect on buying behavior and brand image. In addition, it is also known that brand image has an effect on brand loyalty. From the results of this study it can be concluded that the existence of advertising of a product is very influential in increasing product purchases by consumers. The increased purchase of these products is also one indicator of the 
strengthening of brand image and consumer loyalty.

Satisfaction identification within each consumer type (passive, rational-active, and relationaldependent) provides a reason to repurchase the same product or recommend it to others. Rationalactive and relational-dependent consumers are found to be dominant consumer who actively search for information before purchasing a product and thus perceive a higher level of satisfaction than do passive consumers (Wahyuningsih \& tanamal, 2008:25).

Mirabi et al. (2015) who examined factors that influence customer buying interest found that product quality, advertising and brand image had a dominant influence on customer buying interest with product quality as the first factor that affected. This certainly shows that product quality is a key factor. As with many other products, because the quality influences the purchase interest of the product, business actors must really place the product quality appropriately according to the target market and be supported by advertisements to encourage consumers to buy products. Seeing that brand image has a positive effect on buying interest, consumers must be educated to have high brand awareness.

The same results are shown by Linda and Herawaty (2017) in her research on the factors that influence decisions in South Tapanuli. It is known that the combination of marketing and product quality has a simultaneous and significant effect on Pandaraman rice purchasing decisions. Marketing mix variable has the most dominant influence in purchasing decisions. Marketing mix and product quality separately are also significant positive influences on purchasing decisions. Therefore the influence dominance of the marketing mix on purchasing decisions must be followed up with strategic steps to strengthen marketing to optimize product sales. Advertising does play an important role because it shapes people's attitudes and perceptions that influence purchasing decisions. Consumer research in Gujranwala, Punjab, Pakistan, the results showed that advertising and consumer perceptions were significantly positively related to consumer purchasing behavior (Malik, 2014). It is also known that the impact of advertising on consumer buying behavior is greater than the impact of consumer perceptions. Consumer purchasing behavior can be improved by quality and creative advertising.

\section{Fostering MSMEs}

After economic growth slowed since 2011, Indonesia's MSMEs sector was able to grow by $2 \%$. At the end of 2013, from 57.9 million MSMEs were able to contribute $99.9 \%$ of the total companies with $2.4 \%$ growth per year (Shinozaki et.al, 2015). In 2011, a growth of $77.6 \%$ actually came from agriculture, forestry and trade. This shows that MSMEs have a sufficiently strong carrying capacity for the Indonesian economy. 
The MSME's carrying capacity for the regional economy also cannot be considered light. With such great carrying capacity, to increase its competitiveness in innovation, entrepreneurship, human resources, finance, market potential and business strategy, They need government to develop marketing networks and financial access (Anton, 2015).

There two interesting facts about MSMEs in Indonesia : (1) MSME's are of overwhelming importance that accounted for more than $90 \%$ of all existing firms and may be a positive sign of ongoing entrepreneurship development in the country; (2) The main constraints faced by MSMEs are financial limitation access to formal source of credit and marketing difficulties (Tambunan, 2011:43).

\section{METHOD, DATA, AND ANALYSIS}

The analytical method in this research is the quantitative method with the analytical tool used which is descriptive statistics (descriptive analysis, validity test, reliability test, multiple regression, t-test, and F-test). Classic assumption tests were also used with multicollinearity tests, normality, autocorrelation, and heteroscedasticity. Variables analyzed consisted in product quality, image, price, promotion, service quality and purchasing decisions of dawet ireng.

Descriptive analysis is done through analysis of supporting data and documents from research results. Supporting data is obtained through follow-up observations on dawet ireng SME's or consumers in Purworejo, Kutoarjo, Pituruh, Bayan, Kemiri, Gebang, and Grabag Districts. It is expected to be able to find the ideal modeling concept for dawet ireng development as a Purworejo superior local product which can then be used as input for the planning and empowerment program for SME, especially through the Office of Cooperative, SME and Trade in Purworejo Regency.

The population of this research is consumers from around 40 dawet ireng SMSMEs in Purworejo. The sampling technique is using the Non Probability Sampling method, amounting to 375 respondents.

\section{RESULT AND DISCUSSION}

\section{Statistical Test Results}

The statistical tests results on consumer perceptions of dawet ireng as a typical culinary Purworejo, it is known that simultaneously there is a strong enough relationship and positive correlation of product quality, image, price, promotion and purchasing decisions. it is based on the $\mathrm{F}$-test results, that value is 46.451 (> Ftable: 2.40).

At the $5 \%$ significance level, based on the results of the t-test it turns out that the product quality variable does not significantly influence the purchasing decision. Whereas the image, price and promotion show a significant positive correlation to the purchasing decisions of dawet ireng. The most dominant influential variable is 
promotion with $\mathrm{t}$-count of 6.820 (primary data processed, 2017). Although the quality of the product does not directly affect the purchasing decision, the essence of the product quality is included in promotion and product image of dawet ireng. This is in line with the results of Repastiningsih (2013) research which shows that the price and quality of each product and simultaneously have a significant effect on dawet ireng purchasing decisions.

\section{Dawet Ireng Development Model}

Based on data and information on the results of observations and interviews with dawet ireng MSMEs at Purworejo, they have several main problems :

1. Marketing dawet ireng drinks

2. Competition with other beverage MSMEs.

3. Efforts to increase income through dawet ireng drinks.

4. Local Government supports.

Based on the problem, it is necessary to develop a model of dawet ireng in an integrated manner. The components that must be involved in the development of dawet ireng are MSMEs, community, local government, private institutions and universities.

The research results which shows that product quality, image, price and promotion have an effect on purchasing decisions, dawet ireng MSMEs must dare to take strategic steps to develop products through an integrated marketing strategy.

The Regional Government, especially through the Office of Cooperative, SME and Trade of Purworejo Regency, must play an active role in fostering and empowering SMEs in the village through various programs. The Office of Tourism and Culture must also play a role in supporting the dawet ireng image strengthening. The synergy of the local government with state-owned enterprises, private institutions, universities and other elements is an important aspect of dawet ireng growth.

To get maximum results, all of these components cannot run independently in developing dawet ireng. This is because the failure or lack of optimal development and empowerment programs in various fields by the regional government is often caused by a lack of synergy between government components with the private sector and the community.

Therefore we need a dawet ireng development model to provide a more complex and comprehensive the related elements and aspects of their involvement. By looking at some of the previous studies results, it can be compiled a description of the concept of dawet ireng development model as shown below. 
INDONESIAN JOURNAL OF BUSINESS AND ECONOMICS Vol. 1 Issue 2, December 2018
Printed ISSN 2621-6167, e-ISSN 2621-4466 https://journal.uniku.ac.id/index.php/ijbe

\section{Figure 1. Dawet Ireng Development Model As Purworejo's Distinguished Local Product}

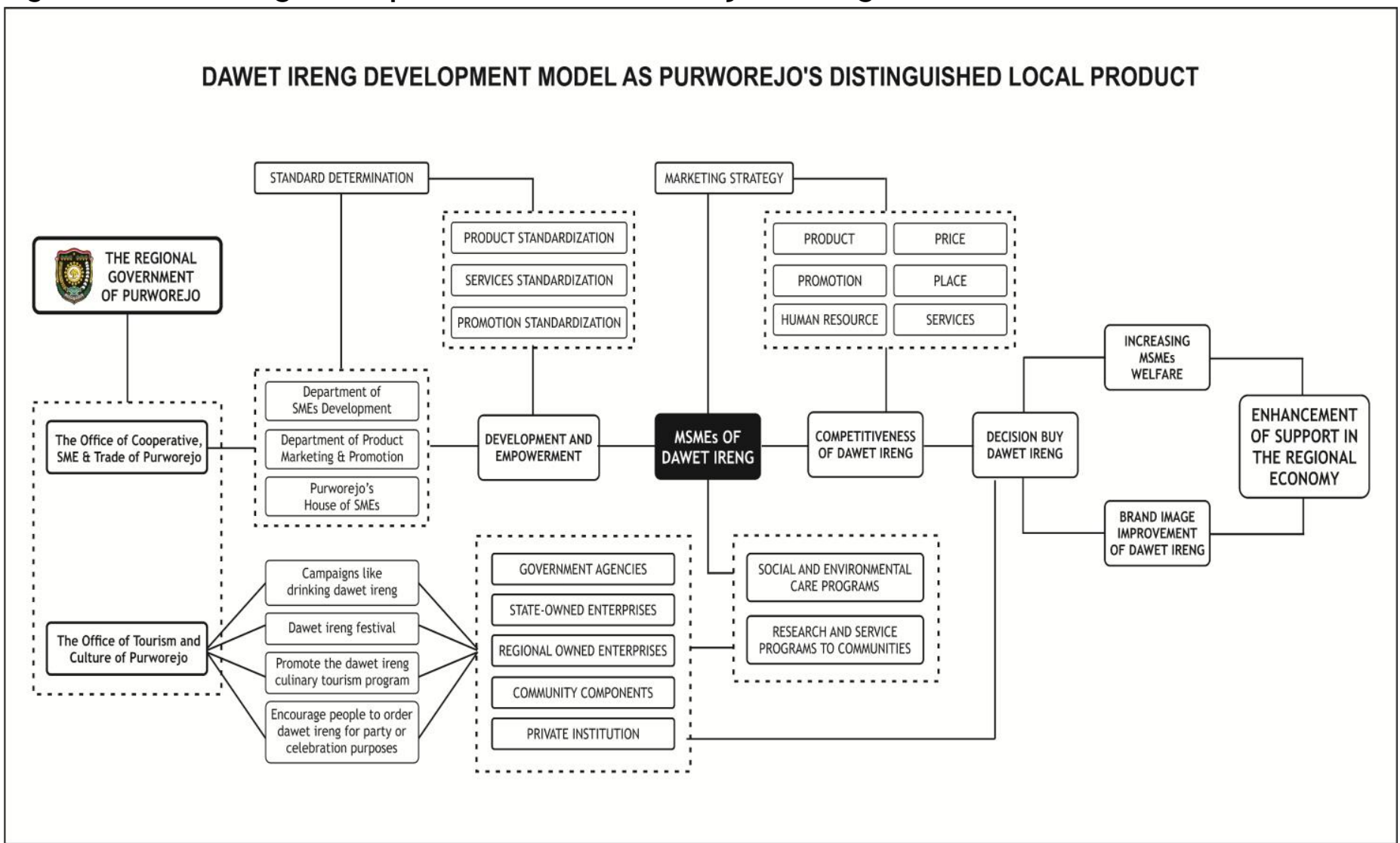

Source: Primary \& Secondary data processed, 2017 
District Government through the Office of Cooperative, SME and Trade to be able to provide guidance and empowerment for Dawet Ireng SME's through strategic programs. This training is carried out through the SME Section as well as the product marketing and promotion section. Besides that, Griya UMKM (MSME's House) of Purworejo Regency as one of the formation team of the Office of Cooperative, SME and Trade played a role in the coaching program, there are consists of elements from the Regional Government Work Unit, universities, SMEs and community groups.

The Office of Cooperative, SME and Trade should establish a standard or basic guideline in dawet ireng development as one of the iconic superior products. The standards set include products, services and promotions aspects.

Standardized products that are set can include:

1. Product quality

a. Dawet ireng pure uses safe natural dyes namely water from the soaking of rice husk combustion.

b. The sweetener or syrup is not mixed with artificial sweeteners but uses pure coconut sugar cooked in addition to natural spices. The sauce is used after one week of cooking to produce a distinctive aroma of Javanese sugar and more legitimate.

c. Coconut milk has been boiled mature so it's more hygienic. d. Ice cubes are made not from uncooked water but using boiled water or natural mineral water.

2. Views and Variants

a. Dawet ireng appearance can be matched with the addition of several additional material as a product variation and diversification.

b. To add to the taste sensation, appearance and nutritional or mineral content, dawet ireng can be varied with some nutritious supporting ingredients such as sweetened condensed milk, cheese or grated chocolate, cocochip, sow chocolate, bread slices or biscuits, young coconut, fruit slices, or sticky tape. Even dawet ireng is also very fitting combined with ice cream.

c. In addition to using original coconut sugar sauce, as an option and product variant, can also make ginger sugar sauce or other natural herbs. This of course will provide more sensation with the support of product value for health because there are elements of natural spices.

3. Packaging and Presentation

a. Dawet ireng stock placement does not use glass or plastic jars but uses clay barrels. Dipper can also use traditional products from coconut shells.

b. The presentation uses a bowl and clay placemat to give a more traditional and distinctive impression. If don't 
use a clay bowl, dawet ireng can also be served with a coconut shell bowl.

c. The spoon does not use a standard spoon made from stainless steel but uses a spoon made from natural coconut shells.

d. Especially for dawet ireng products that are not taken in place, can use hygienic and safe plastic cups for food.

e. Dawet ireng presentation must be done hygienically, clean and neat.

Various changes applied to dawet ireng products can be followed directly or indirectly with new pricing uniformly. This means being a process of improving the position and bargaining power of dawet ireng products to consumers. With combinations and variations along with these supporting materials, dawet ireng can be offered at a better price, which is between IDR 5,000 and IDR 10,000. It is also possible to do a price strategy through various options such as discounts, promotional prices, wholesale prices and others. As a special attraction, a system fee or special bonus can also be applied to orders in large quantities.

Changes in product quality, ingredients composition, additives, portion size, equipment, presentation methods, and excellent service followed by price adjustments can have a positive effect:

1. Increase the profits value for dawet ireng SMEs because consumers become more interested in buying dawet ireng. Besides of higher profit margins, dawet ireng basic price is better than before.

2. The attractiveness of dawet ireng for consumers will strengthen dawet ireng brand image as a Purworejo superior local product typical that is different from similar beverage products with modern nuances.

3. Dawet Ireng as an icon of Purworejo is better able to be equated with drinks that are modern and contemporary so they can penetrate various circles of society and have a wider market share. This is especially true for students and young people who have tended to like drinks other than dawet ireng.

While the services standardization can be applied as follows:

1. Clothing sellers dawet ireng tried to have a distinctive value or represent the "regional" or traditional characteristics. For example, men using surjan clothes, headbands, trousers and sandals made from rubber tires. While clothes for women use a kebaya top shirt that is combined with batik shades such as jarik old cloth. This is to give a classic feel of "the old days".

2. Referring to servqual (service quality) model to measure the customers expectations and perceptions on aspects of service (Parasuraman, 1988), dawet ireng service should attention to 
service quality dimensions as

follows:

Table 2. Application of service quality standards to dawet Ireng SMEs

\begin{tabular}{l} 
Reliability \\
\hline 1. Dawet ireng seller serves deftly, \\
skillully and convincingly. \\
2. When receiving an order must \\
maintain timeliness. \\
3. Not discriminating services to all \\
consumers. \\
4. Avoid various mistakes from small \\
things, such as less coconut sugar \\
sauce dose, forget not given \\
coconut milk or the other.
\end{tabular}

5. The seller must be sympathetic to consumers.

\begin{tabular}{l}
\hline \multicolumn{2}{|c|}{ Assurance } \\
\hline 1. The seller must be polite, \\
friendly and trustworthy. \\
2. Apply smile, greet, greetings to \\
consumers sincerely.
\end{tabular}

3. Maintain product quality and its supporting aspects so that consumers are confident and believe that hygienic dawet ireng is safe for consumption and is truly a superior product.

4. Prioritizing the consumers interests and not just looking for profit.

\section{Responsiveness}

1. Willing to help consumers dawet ireng quickly and wholeheartedly when they need help.

2. Do not let consumers wait without clarity when buying or ordering dawet ireng.

3. Do not delay service to consumers without logical or unclear reasons.

4. Prioritize or prioritize service to consumers
1. Dawet ireng selling place must be neat, clean and not dirty to provide comfort for consumers.

2. All equipment must be clean and suitable for use.

3. The seller must be neat, clean with typical apron and clothing

4. The available communication media are optimal and easily accessible by consumers. For example, keeping the phone always ready to be contacted at any time.

1. The seller of dawet ireng must show full attention when serving consumers or customers.

2. Providing convenience in good communication, including the use of telephone devices or smartphone-based services.

3. Understanding the customers character and needs specifically so that services can be done more accurately. For example, when a customer usually buys with a special request in the form of a reduced amount of coconut sugar sauce, the seller must be careful about this.

4. The time and day of opening must provide convenience for customers to minimize consumers disappointment who want to buy dawet ireng. Opening hours must be consistent and 
unchanging and easily identified by consumers. If you have to leave, you can give clear information to consumers.

Source: Primary and Secondary data processed, 2017

Dawet ireng promotion aspects improvement in order to be able to increase sales and represent the image of a Purworejo superior local product typical can be done by dawet ireng SMEs with standard references as follows:

1. Promotional devices must further highlight Purworejo's branding logo as determined by the regional government. This standard is applied to various advertising promotion media such as banners, hdpe plastic bags, plastic cups, aprons and more.

Figure 2. Purworejo Branding Logo

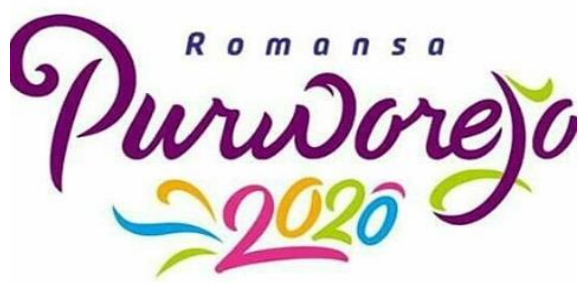

2. The color and design of promotion media device should be given a standard reference to strengthen characteristics of Purworejo products.

3. For dawet ireng which is not eaten on the spot, SMEs appealed to use a plastic cup specifically logo business name as a brand as well as product promotion.

4. The pickup cart as a typical equipment of dawet ireng can be packaged with modern and presentable nuance, but without leaving its distinctive aspect.
5. Dawet Ireng SMEs are encouraged to use information technology and online social media to promote Dawet Ireng, while at the same time socializing local Purworejo products regularly and continuously.

The standards set by The Office of Cooperative, SME and Trade will be the priority aspects emphasized in fostering business operators in dawet ireng. These standards and the coaching process, SMEs apply them in a technical marketing strategy. Various components can take a strategic role in optimizing the empowerment of dawet ireng SMEs. These components include related institutions from the ranks of local government, National or Regional Enterprise, private agencies, universities and other components.

For example, state-owned enterprises in Purworejo can support strengthening promotion through the social and environmental care program with integrated CSR (Corporate Social Responsibility) funds. This certainly will reduce the cost burden that must be borne by dawet ireng SMEs. While the higher education, aside from being directly involved in coaching program by related regional office, can also support with various research programs and community services whose benefits can also be felt by SMEs in real terms. 
Agus Fitri Yanto, Danis Imam Bachtiar

Dawet Ireng Development Model as Purworejo's Distinguished Local Product

Marketing strategy adopted by dawet ireng SMEs covers aspects of the product, price, place (location and distribution), promotion, human resources and service activities. Dawet ireng SMEs must understand that their business are not just for profit but also has a mission to strengthen dawet ireng growth and development as a superior typical local product. Marketing strategy implemented in an integrated manner will be able to strengthen dawet ireng competitiveness so as to increase purchases by the consumer.

As we know the results of research in the field show that $61.33 \%$ of consumers buy dawet ireng $<3$ times in one month. As many as $66.66 \%$ of them actually buy similar drinks in addition to dawet ireng at least three times in one month (Yanto \& Bachtiar, 2017). Such drinks include juice, factoryproduced instant drinks, ice blenders, capucino ice, chocolate drinks, fruit soups and more. Even though the prices set by dawet ireng traders are currently in the range of IDR 3,000 to IDR 4,000 per serving (bowl).

While similar beverage products can be sold in the range of prices starting at IDR 5,000 to IDR 10,000 per portion. This is an indication that the public as a beverage consumer has a high purchasing power above the dawet ireng price that applies in market. Marketing strategy of dawet ireng must be able to shift the consumers decision who previously bought similar drinks to prefer dawet ireng.

While the Tourism and Culture Office of Purworejo Regency can take an active role in developing dawet ireng in the community through various programs. The program includes:

1. Campaigns like drinking dawet ireng for students and the younger generation through community groups.

This is accordance with the research by Salehudin (2016:1) which shows that exposure to the buy local promotion campaign does increase consumer ethnocentrism, attitude toward the campaign and toward domestic products. Consumer ethnocentrism does increase attitude toward domestic product and willingness to purchase local products.

2. Dawet ireng festival is packaged as a routine annual event to further popularize dawet ireng as a Purworejo's typical local drink. This event can be held together with other routine events such as Purworejo Expo, commemoration of Purworejo anniversary and others.

3. Promote the dawet ireng culinary tourism program combined with promotional activities and potential tourism and cultural programs in Purworejo Region.

4. Encourage people to order dawet ireng for party or celebration purposes, rather than using other similar products.

Indirectly this will encourage people in various layers to increase the amount of consumption of dawet ireng so as to lift the dawet ireng brand image. In addition, it is also indirectly able to improve the welfare of dawet ireng SMEs. If this 
INDONESIAN JOURNAL OF BUSINESS AND ECONOMICS Vol. 1 Issue 2, December 2018

can occur synergistically, dawet ireng carrying capacity in regional economic growth will be more optimally sustainable.

\section{CONCLUSIONS}

From the results of the study or analysis of research data on dawet ireng purchasing decisions and other related studies it can be concluded that the marketing mix strategy are very influential in purchasing decisions. Mixes that need attention include product quality, brand image, price, promotion and service.

Because dawet reng MSMEs have problems in marketing dawet ireng drinks, competition with other beverage MSMEs, efforts to increase income through dawet ireng drinks and Local Government supports, so is necessary to develop a model of dawet ireng in an integrated manner. The components that must be involved in the development of dawet ireng are MSMEs, community, local government, private institutions and universities.

\section{IMPLICATION/ LIMITATION AND SUGGESTION}

In this case the dawet ireng development as one of the iconic superior local products of Purworejo must be carried out simultaneously, continuously, programmed, and integrated by the local government through the Office of Cooperative, SME and Trade, andTourism and Culture Office, involving relevant agencies, National Enterprises, private institutions, universities and other community components.

While it's not too late, handling dawet ireng must be done immediately. Therefore looking at the urgency aspect to improve brand image and its competitiveness among similar products, the concept of dawet ireng development model can be immediately followed up with program discussions and planning which are subsequently established, implemented, implemented and monitored with all related components so that they can be it is truly an icon of Purworejo's superior local product, the pride of the community.

\section{ACKNOWLEDGMENT}

The research before is facilitated by Directorate of Research and Community Service, General Directorate for Research and Development - Ministry of Research, Technology and Higher Education Republic of Indonesia through Lecturer Research Program 2017.

\section{REFERENCE}

Anton S. A., Muzakan I., Muhammad W. F., Syamsudin, Sidiq N. P. An Assessment of SME Competitiveness in Indonesia. Journal of Competitiveness, 7(2), 60 - 74.

Ambolau, M. A., Kusumawati P. A., Mawardi, M. K. (2015). The Influence of Brand Awareness and Brand Image on Purchase 
Agus Fitri Yanto, Danis Imam Bachtiar

Dawet Ireng Development Model as Purworejo's Distinguished Local Product

Decision. Jurnal Administrasi Bisnis, 2(2), 1-8.

Bank Indonesia. (2010). Survei Daya Saing (SDS) 2010 di Jawa Tengah, Wujud Nyata Penghargaan Terhadap Upaya Pemerintah Daerah Dalam Pembangunan Ekonomi Daerah. http://www.bi.go.id/id/publika si/kajian-ekonomi-regional/ jateng/Documents / 7e8fe6b8c25 04b16a47adcf048eb4c35BOKS SurveiDayaSaingDaerahJawaTen gah2010.pdf. Diakses 26 Oktober 2017.

Chakrabortty, R. K., Md. M. Hossain, Md. F. H. Azad \& Md. J. Islam. (2013). Analysing the Effects of Sales Promotion and Advertising on Consumer's Purchase Behaviour. World Journal of Social Sciences, 3(4), 183 - 194.

Darwanto. (2013). Peningkatan Daya Saing UMKM Berbasis Inovasi dan Kreativitas Rategi Penguatan Property Right Terhadap Inovasi dan Kreativitas. Jurnal Bisnis dan Ekonomi, 2(2), 142-149.

Durrani, B.,A., Godil D. I., Baig M. U., Sajid S. (2015). Impact of Brand Image on Buying Behaviour Among Teenagers. European Scientific Journal, 11(5/0, 155-168.

Hossain. (2007). An Evaluation of Brands Image, Product Attributes and Perceived Quality of a Selected Consumer Nondurable

Product.
Administration and Management Review, 19(2), 47-63.

Linda Sipayung, M., A. Herawaty Sinaga. (2017). Marketing Mix Effect and Quality Product Purchase Decision on Rice Pandaraman in South Tapanuli Region. IOSR Journal of Business and Management (IOSR-JBM), 19(3), 85-89.

Lin, N.H. (2007). The Effect of Brand Image and Product Knowledge on Purchase Intention Moderated by Price Discount. Journal of International Management Studies, August 2007, 121-132.

Malik, M. E., Ghafoor, M. M., lqbal, H. K., Unzila, \& Ayesha. (2014). The Impact of Advertisement and Consumer Perception on Consumer Buying Behavior. International Review of Social Sciences and Humanities, 6(2), 55-64.

Mendez M., M. Bendixen, R. Abratt, Y. Yurova, B. O'Leary. (2015). Sales Promotion and Brand Loyalty: Some New Insights. International Journal of Education and Social Science, 2(1), 103-117.

Mirabi, V., Tahmasebifard, H., Akbariyeh, H., (2015). A Study of Factors Affecting on Customers Purchase Intention (Case Study: the Agencies of Bono Brand Tile in Tehran). Journal of Multidisciplinary 
INDONESIAN JOURNAL OF BUSINESS AND ECONOMICS Vol. 1 Issue 2, December 2018

Engineering Science and
Technology, 2(1), 267-273.

Oladepo, O. I., Abimbola, O. S.. (2015). The Influence Of Brand Image And Promotional Mix On Consumer Buying Decision A Study Of Beverage Consumers In Lagos State, Nigeria. British Journal of Marketing Studies, 3(4), 97-109.

Parasuraman, A. Valerie, A. Zeithaml, \& L. Berry. (1988). The Service Quality Puzzle. Journal of Marketing Business Horizon, 49 (Fall), 44.

Pramono O., E. (2015). Formulasi Strategi Usaha Makanan Ringan Tradisional Ny. Gan di Surabaya. AGORA, 3(2), 665-674.

Respatiningsih, H. (2013). Pengaruh Harga Dan Kualitas Produk Terhadap Keputusan Pembelian Dawet Ireng Jembatan Butuh Kecamatan Butuh Kabupaten Purworejo. MEDIKONIS, 6(1), 1 22.

Sapna \& Sheetal. (2016). Brand Image and Its Impact on Buying Behavior. International Research Journal of Commerce and Law (IRJCL), 03(02), 9-16.

Sagala C., Destriani, M., Putri, U. K., Kumar, S.. (2014). Influence of Promotional Mix and Price on Customer Buying Decision toward Fast Food sector: A survey on University Students in Jabodetabek Indonesia. International Journal of
Printed ISSN 2621-6167, e-ISSN 2621-4466 https://journal.uniku.ac.id/index.php/ijbe

Scientific and Research Publications, 4(1), 1-7.

Salehudin, I. (2016). 100\% Indonesia: Role of Government Campaign to Promote Local Products in Indonesia. Asean Marketing Journal, 8(1), 1-17.

Saputra, D., Waluyo, H. D., Listyorini, S. (2014). Effect of Product Quality, Promotion, and Brand Image on Purchase Decision of Nike Sports Shoes (Case Study on S1 FISIP UNDIP Students). Diponegoro Journal of Social and Politic, 1-12.

Setiawati, D., Istiyanti, E., \& Hasanah U. (2013) Kontribusi Pendapatan Agroindustri Dawet Ireng Terhadap Pendapatan Keluarga Pengrajin Di Kecamatan Butuh Kabupaten Purworejo. Surya Agritama, 2(2), 13-22.

Shinozaki S., Chaiken, T., Jain, S., Dorofev, K., Santos, C. T. D., \& Bautista, J. (2015). Indonesian SME Landscape. Asia SME Finance Monitor 2014 : Asian Development Bank. 169

Tambunan, T. T. H. (2011). Development of Micro, Small and Medium Enterprises and Their Constraints: A Story from Indonesia. Gadjah Mada International Journal of Business. 13 (1), 21 - 43.

Wahyuningsih, Tanamal, J. (2008). A Study On Customer Satisfaction Across Information Search 
Agus Fitri Yanto, Danis Imam Bachtiar

Dawet Ireng Development Model as Purworejo's Distinguished Local Product

Behavior Typology. Gadjah Mada

International Journal of Business, 10(1), 25-46.

Widyastuti, S., Santosa, B. (2016).

Green Marketing: A Study of the
Factors Influencing the

Repurchase Decision for Javanony Herbal Products. Asean Marketing Journal, 8 (2), 104-115. 